

\section{Abstract}

At the turn of the twentieth century, the Japanese government passed a series of laws targeting people diagnosed with Hansen's Disease (leprosy). As a result, many patients were quarantined in public leprosaria, often for life. In order to cope with both the diagnosis of a heavily stigmatized illness and a lifetime in isolation, patients began to write. The works produced by sufferers became so popular that by the mid-1930s their writing was referred to as a distinct literary genre, "leprosy literature."

Studies of leprosy literature have focused on its depiction of human rights violations, struggles with the illness, and the difficulty of life in quarantine. However, patient writing in the 1930s also reveals the multiple ways in which patients found happiness within the institution. In this sense, leprosy literature is also a site of translation, revealing the negotiations of hospital life involving hospital and medical authorities, patients, leprosy relief groups, and government policies. Residents of the leprosaria represent happiness in multiple ways depending on their conception of their illness and life in the leprosaria. For some patients, the institution itself was a source of happiness in that their illness was stigmatized to the degree that life outside the hospital became unbearable. Other writers chafed at life in the hospital; the translation of happiness in their writing is a more complex process. This paper takes these diverse processes of translation as its starting point and examines the multiple ways in which patients conceived of health and happiness within the confines of hospital life.

Keywords: leprosy; Hansen's Disease; poetry; Japan; literature; tanka 


\title{
Contested Histories and Happiness:
}

\author{
Leprosy literature in Japan
}

\section{K. M. Tanaka}

\section{Introduction}

Hansen's Disease has a long history in Japan, with its earliest records dating to the Nara period (AD 710-784), ${ }^{1}$ wherein the illness was associated with immorality or considered a transgression of Buddhist precepts. While premodern records of the social treatment of sufferers of the illness are scarce, by the eleventh century communities of sufferers who had been cast out of their villages began to appear around temples to beg for alms, as they had no other means to support themselves (Burns 2003). That the disease was seen as karmic retribution for sinful behavior did not mean that salvation and/or enlightenment was not possible, for at the same time Buddhism described an ethics of compassion towards sufferers, identifying their gentle treatment as a path to enlightenment through the many Buddhist tales featuring bodhisattvas disguised as Hansen's Disease sufferers (Burns 2003). Thus, as Susan Burns convincingly argues "the sufferer of leprosy was an ambivalent figure in medieval culture, seemingly the physical manifestation of sin, but also potentially capable of bringing salvation to one who offered compassion" (Burns 2003, 106). Indeed, the earliest homes for sufferers of Hansen's Disease were Buddhist facilities, established in the Kamakura period (1185-1333) (Yamamoto 1997; Burns 2003). In addition to these early Buddhist facilities, Jesuit missionaries in the sixteenth century established facilities to house patients (Author, 2012). Yet, the object of the provision of both Buddhist and Christian refuge for sufferers in medieval Japan was religious conversion rather than treatment (Burns 2003).

While there is evidence that as early as the eleventh century patients began to congregate in "leper villages," by the Tokugawa period (1603-1867) ideas about caste and an increasing social prejudice led to the establishment of independent communities for those who had been forced out of their homes. Sufferers established villages in places of religious significance, such as the Buddhist temple Honmyō-ji in Kyushu, or in sites which were reputed to have curative powers, such as the hot springs village of Kusatsu in Gunma. These communities continued to develop into the twentieth century and included healthy residents who would live and work alongside sufferers (Hirokawa, 2010). While sufferers of Hansen's Disease undoubtedly experienced stigma prior to the

${ }^{1}$ Persons diagnosed with Hansen's Disease have advocated the use of that term rather than "leprosy". In this paper the word "leprosy" is retained when quoting material that used the now-pejorative Japanese term rai (leprosy) or when referring to the pre-Promin literary genre of leprosy literature. We use the term Hansen's Disease in all discussion and when translating material that employs term Hansen-byō (Hansen's Disease). 
enactment of effective legislation targeting their illness, Hirokawa's work has demonstrated that sufferers at a local level were often able to integrate into communities and live a "normal" life.

By 1867, the Tokugawa shogunate fell and power was returned to the emperor in the Meiji Restoration. This led to enormous changes in political and social structures as the Japanese government began to implement policies and reforms based on modern Western models. Scholars have long argued that Hansen's Disease was associated with non-European, specifically colonial populations and for this reason the Meiji government targeted sufferers (Gussow, 1989; Sawano 1994; Anderson 2006; Edmund 2006). Moreover, recent scholarship, such as that of Susan Burns and Hirokawa Waka, has sought to provide a more complex history of Hansen's Disease in Japan by tracing the ways in which media attention, religious missionary activities, and changing medical knowledge all contributed to the perception of Hansen's Disease as a national shame and shaped the design of state policies (Burns, 2012; Hirokawa, 2010). ${ }^{2}$

During the Meiji period, the earliest sites of refuge and treatment were facilities established by practitioners who used "patent medicine" to treat sufferers (Burns 2012) and in the 1880s, Christian missionaries also began to create homes to treat patients. However, it was not until 1907 that the Japanese government passed the first in a series of laws establishing public sanatoria and a quarantine policy for those diagnosed with Hansen's Disease. The 1907 "Law Concerning the Prevention of Leprosy" was principally aimed at providing facilities for the care of itinerant sufferers, such as those who begged at temples. The law divided the nation into five prefectural districts and required each group to open a public, joint-prefectural hospital to receive vagrant patients. In this way, each prefectural group opened a single hospital, resulting in a total of five public hospitals established under the 1907 law. After the first facilities opened in 1909, in some cases patients with the financial and familial means to receive home treatment requested admittance to these treatment facilities so as to protect their families from discrimination (Author, 2012). Thus, it was possible under the 1907 law for patients to seek treatment of their own volition, while poorer sufferers could be forcibly quarantined. And because patients were to be institutionalized until they were no longer deemed infectious, for many sufferers the hospitals became not only sites of medical care, but also communities where patients collectively spent their lives.

In the late 1920s and early 1930s the disease became the target of increased social and political attention. In 1929, a social movement to rid the region of Hansen's Disease began to emerge in Aichi prefecture which was eventually dubbed the "Leprosy-Free Prefecture Movement" (murai ken undo). The murai ken undo spread across Japan, advertising Hansen's Disease as a highly contagious disease (Yamamoto 1997), urging the evacuation of sufferers to public institutions and at the same time signaling an intensified shift in public attention. In 1931, the "Law Concerning the Prevention of Leprosy" underwent revision to allow for the institutionalization of all actively infectious cases of Hansen's Disease (Hirokawa, 2010). This resulted in the 1931 "Leprosy Prevention Law" which was unevenly applied, with some prefectures urging the institutionalization of all cases, infectious or not, and other regions continuing to allow home treatment (Hirokawa, 2010). 1931 was also the year the first national hospital for Hansen's Disease, Nagashima Aisei-en, opened on an island off the coast of Okayama in the Inland Sea, and the year in which the Leprosy Prevention Association (Rai yobō kyōkai) was founded through the support of the famed industrialist, Shibusawa Eiichi (1840-1931), and donations from the imperial family. ${ }^{3}$

2 This article follows the Japanese convention of listing the family name first and the given name secondarily.

${ }^{3}$ One of the main goals of the Association was to foster public awareness for government policies and encourage compliance with isolation policies. 
In part because one of the consequences of the 1931 law was the increase in patient populations at public facilities, groups and collectives of patients who used literature as a way to create communities within the hospital also became more popular. Resident patients had formed poetry coteries and began to publish their work soon after the first public leprosy hospitals opened in 1909, and eventually, such works attracted enough attention from literary critics that by the late 1930s they were referred to in newspaper and magazine articles as a distinct literary genre leprosy literature. While "leprosy literature" and "Hansen's Disease literature" are now used synonymously in Japan, they are in fact distinct categories, with different authorial intentions and social functions. ${ }^{4}$ Whereas leprosy literature was written in the pre-Promin era of public hospitalization (1909-1946) when there was no effective treatment for the illness, Hansen's Disease literature is a product of the post-Promin period (1946-present), when the disease became curable, first with the medication Promin and later with multidrug therapies. As treatments for the illness progressed, residents during the post-Promin period campaigned for the social status of patients to change in order to reflect medical advances.

Influenced by the struggles of Hansen's Disease survivors who wrote in the post-Promin period, studies of patient writing in Japan have focused primarily on either prose fiction or on the works of individual authors. These studies have tended to analyze patient writing as assertions of dignity in the midst of oppression that occurred within the hospital. ${ }^{5}$ Although recent scholarship by Arai Yuki (2011), in particular, has sought to complicate the role of patient writing and the quarantine experience, the trajectory of scholarship on patient writing has typically been to read it as testimony to difficult hospital conditions and the struggle with defining what it means to be human in the face of a devastating illness. ${ }^{6}$

In particular, patient writing that expresses contentment or describes the happiness found in the hospital has been dismissed as writing coerced from patients to promote both hospital and government policies. However, as this present study seeks to demonstrate, patient writing is not an either/or proposition but a site of what Nikolas Rose (1999) has called "translation," where "in the dynamics of translation, alignments are forged between the objectives of authorities wishing to govern and the personal projects of those organizations, groups and individuals who are the subjects of government." (p. 48). With the written word patients described sources of happiness which on occasion led to alignments with hospital officials or government policy. Moreover, writing was also an expression of personal autonomy, a way in which patients defined and negotiated happiness for themselves. Rose further notes that translation allows for governance as citizens are "made up" through a variety of authorities and institutions. In this way, "personal autonomy is not the antithesis of political power, but a key term in its exercise, the more so because most individuals are not merely the subjects of power but play a part in its operations." (Rose \& Miller, 1992, p. 174)

${ }^{4}$ See Author (2012), for more on the issue of the name of the genre and English-language scholarship on Hansen's Disease in Japan.

${ }^{5}$ In addition to Arai (2011), see Morita (2003) and Yamashita (2003) among other studies on patient writing. For examples of individual author studies on the most well-known patient poet, Akashi Kaijin (1901-1939), see Aranami (2000) and Kurihara (1987). For studies of the prose fiction writer often referred to as the founder of the genre, Hōjō Tamio (1914-1937), see Mitsuoka (1981) and Takayama (1999).

${ }^{6}$ Rather than a single author study, Arai (2011) broadly rereads the genre of patient writing. Although Arai does not explicitly use the term "translation", his work on patient identity reveals patient writing to be a complex negotiation that reflects multiple perspectives. In addition, studies, such as those by Araragi Yukiko (2004) and Sakata Katsuhiko (2012), also describe the negotiations involved in hospital life as detailed in patient testimony. 
Rose utilizes the concept of translation to speak of government as a "historically construed matrix within which are articulated all those dreams, schemes, strategies and maneuvers of authorities that seek to shape the beliefs, and conduct of others in desired directions by acting upon their will, their circumstances or their environment," a process reflected in the social and political factors that helped shape life within the hospital and its depiction in patient writing (Rose \& Miller, 1992, p. 175). Attention to processes of translation demonstrates how patients translated their duty as a citizen; it also reveals how patients made a community in public hospitals and how, amidst social stigma, patients negotiated their life in the institution with medical authorities, government policies, and Hansen's Disease relief organizations.

What government policies and Hansen's Disease relief groups sought to "make up" and promote in the early 1930s was a citizen who was willing to be hospitalized for the good of the nation, with every effort aiming for the eradication of the illness from the Japanese social landscape. While there were patients who participated in these objectives and in doing so attained a degree of happiness or contentment in their lives by sacrificing themselves to what they perceived to be the greater, national good, there were others who sought to create their own conditions of happiness; the literature therefore reveals the multiple ways in which sources of happiness within the public sanatoria were created and defined. Indeed, literature as a medium through which to gauge happiness has been largely overlooked by studies that focus on the economic or institutional measures of well-being. Yet, literary works provide a glimpse not only into the question of what happiness is, but also how it is attained - that is to say, literature can reveal the complex process of translation involved in attaining a measure of happiness. In particular, pre-Promin leprosy literature reveals the process of translation that led to the hospital being a place of contentment and refuge for many patient writers.

The idea of happiness has received increased attention in recent years as a concept central to the measure of quality of life for a person or country. At the same time, the question of happiness is a difficult one for such a state of being is subject of many variables: how can one thus measure happiness? And what is the difference between happiness, contentment, satisfaction or well-being? Not only is the idea of happiness highly subjective and difficult to objectivity within culturally, historically and economically variable contexts, but also its pursuit and rationalization are concerns of Western rather than Eastern philosophy. Broadly, in Japan, dominant philosophies such as Buddhism, Shintoism, and Confucianism have stressed acceptance of one's fate, so as to develop harmony or contentment through an understanding of the causes and conditions shaping one's life. This said, the Western notion of happiness as a measure of social well-being is in Japan a distinctly post-1945 phenomenon, tied to notions of economic recovery and the industrial growth defining the postwar democracy. ${ }^{7}$ Thus, for residents of Japanese pre-Promin Hansen's Disease hospitals, happiness is most commonly expressed through a notion of doing one's duty for the nation, in viewing the hospital as a welcome escape from the social stigma encountered outside institutional walls, or in the comfort patients found in the care they received from hospital personnel. ${ }^{8}$

This study focuses primarily on patient poetry in order to explore literature as a site of translation that emerged from early public Hansen's Disease hospitals. There are several reasons for this: firstly, although prose fiction has been given the majority of attention in scholarship on patient writing, most patient writers were poets -

7 For more on measures of happiness in postwar Japan, see, for example, Oshio, Kayo \& Kobayashi (2011); Kosaka (2007); Kumano (2011); and Coulmas (2009).

8 Despite the difficulties of measuring subjective notions of happiness, studies of patient writing and life in public hospitals have focused overwhelmingly on patient unhappiness, their struggles with a feared illness, the difficulty of life in quarantine, and the violations of their human rights that occurred within institutions. 
the structure and accessibility of poetry made it an appealing form. Secondly, the first poetry collections published for an audience outside the hospital were volumes of haiku and tanka, and thirdly, compared to prose fiction, Japanese poetry was relatively easy for amateurs to publish autonomously. ${ }^{9}$ Furthermore, poetry was fundamentally a socially contextualized activity, for haiku and tanka were often composed collectively. Doctors also encouraged the patient production of tanka as a means to aid them come to terms with their condition; to that end, medical professionals would help select poems for publication and would sometimes participate in the poetry coteries themselves. ${ }^{10}$ Finally, such poetry also became the basis of connections to communities outside the hospital. Although patients published their own work in coterie magazines and the official hospital magazine (kikanshi), their work was also used in promotional pamphlets distributed by the hospital and by relief groups such as Christian missionary societies and the Leprosy Prevention Association. The poems used in these promotional materials were sometimes solicited expressly for the purpose, but often they were drawn directly from the work of patient writers circulating within the hospital. ${ }^{11}$ Poetry not only presents a variety of voices that are occluded in studies of patient prose, but the poems themselves were published in multiple forums that did not necessarily use prose fiction. By examining these poetic writings it is also possible to identify a translation in process that achieves a distinctive understanding of happiness.

\section{Contested Histories of Hansen's Disease Literature}

In the historical context of Hansen's Disease, the relation between happiness and patient writing is challenging because works that voiced support for institutionalization or revealed contentment within institutional settings have been largely neglected by Japanese scholars. This neglect is due in part to the difficulty of locating the multiple forms of patient writing in publications or archives. Patient literary groups typically circulated their writings through a coterie magazine which could take multiple forms: as handwritten or mimeographed booklets with hand-painted covers; with greater hospital support, typeset coterie magazines or publication in book form. For smaller coteries, a single, handwritten copy of the group's best works for that month would likely have been produced; for example, the archives of Kyushu Hospital (today Kikuchi Keifü-en), contain several well-read issues of a 1927 handwritten journal entitled Kurotsuchi (Black Earth), compiled, copied, and circulated by patient writers. This said, it is difficult to estimate the volume of material lost in accidents, or in the deprivation of wartime and the

${ }^{9}$ Haiku is a short poem composed of seventeen Japanese phonetic units, broken into phrases of five, seven, and five units. Tanka is similar, but longer, consisting of thirty-one phonetic units in phrases of five, seven, five, seven and seven units.

10 Dr. Uchida Mamoru (pen name Uchida Morito) (1900-1982) is perhaps the best-known example of medical professionals supporting patient literature; he started poetry coteries at several hospitals over the course of his career and published numerous edited collections of patient poetry. For more on his medical and literary careers, see Author (2012) and Baba (2004). Dr. Ogawa Masako, who wrote Kojima no Haru [Spring on the Small Island] (first published in 1938; reprinted in 2009), a best-selling diary interspersed with tanka also provided a role model to the women's literary coterie at Nagashima Aisei-en.

${ }^{11}$ For example, a pamphlet for Kyushu Hospital, written in both Japanese and English, introduced patient life in the hospital while soliciting donations to support the institution. In the Japanese section of the Kyushu pamphlet, they included a page of patient haiku and tanka to illustrate the daily life of residents and the way the literary group offered a source of comfort for those struggling with the illness and social isolation. See: Kyushu ryōyōjo annai [Kyushu Leper Asylum Guide Book] (1927), most likely published by Kyushu Hospital itself. 
immediate postwar period; the decentralization of the archives is also problematic for researchers, as each hospital maintains its own collections of materials published or circulated within that institution. ${ }^{12}$

The more easily available works by prominent patient authors, in particular the poet Akashi Kaijin (1901-1939) and the prose writer Hōjō Tamio (1914-1937) has been a factor in the disproportionate attention they have received; but availability is not the only reason for the neglect of lesser-known patient writers. In the case of pre-Promin patient writing, patients who wrote in support of isolation and encouraged recently diagnosed sufferers to leave their homes have been dismissed as nothing more than an institutional propaganda mechanism. ${ }^{13}$ This is partly because of the uses of patient writing by groups and institutions to promote quarantine agendas and the legitimacy of the care the public hospitals provided. Further, most hospital presses published official hospital journals, featuring patient writing; these journals were run by the patients with the involvement and supervision of hospital staff. ${ }^{14}$ Other collections were published by local or even national presses, commonly under the editorship of the medical authorities; in these cases, publication involved at least two levels of censorship: that of hospital officials and then that of the Japanese government censors. ${ }^{15}$

Promotional material in support of government policies, published by both the hospital and the Leprosy Prevention Association, appropriated or used patient writing to advertise the work of the hospital in pamphlets and flyers in order to encourage patients receiving home treatment to enter a government hospital (Arai, 2011). Christian groups, the Hygiene Bureau in the Home Ministry, and the Leprosy Prevention Association all participated in manuscript solicitation and publication. And whilst all groups were interested in offering care to people diagnosed with Hansen's Disease, the promotion of quarantine policies as an effective measure to rid the nation of Hansen's Disease was a primary goal. For the Leprosy Prevention Association, in particular, patient writing was central to the promotion of hygiene ideals. ${ }^{16}$ As Arai (2011) points out, the Association was important in introducing patient writing to an audience outside the hospital and convincing sufferers to seek treatment (p. 41). In addition, Christian missionary workers, in particular Lois Johnson Erickson (1881-1966), the wife of a Christian minister stationed at Takamatsu in Shikoku, published translations of patient writing in English to promote their mission's philanthropy

12 Many of the hospitals do not focus on archival upkeep, which is the biggest hurdle to archival research. The materials that were published or circulated within that hospital are simply kept in a room, or more often several different rooms (a patient library, the publishing office of the hospital, the doctors' library, etc) within the same hospital, without organization or cataloging.

13 Kaijin $(1941,1993)$ and Hōjō $(1938,1996)$ are two of only four sufferers to have had their complete works published, in addition to Shimada Shakusō (1939) and Tō Kazuko (2006).

14 While hospital magazines have yet to receive due attention by scholars, Arai (2011) provides brief but insightful discussion; see also Yamada (2009).

15 It was not only patient writing that was subject to censorship in Japan at this time, although leprosy literature did face additional hurdles in its path to publication, as patient writing from letters to literary manuscripts were monitored and sanitized before being sent out of the hospital. For more on literary censorship in Japan, see, Abel (2012) and Kōno (2009).

16 The edited collections of patient writing published by the Leprosy Prevention Association are: Kanja sakuhin eiga sozai shū dai isshū [Patient Writing, Collected Materials for Movies, Volume One] (1933); Kanja sakuhin eiga sozai shū dai ni shū [Patient Writing, Collected Materials for Movies, Volume Two] (1935); Kanja sakuhin eiga sozai shū dai san shū [Patient Writing, Collected Materials for Movies, Volume Three] (1936); and Kanja sakuhin shū dai isshū [Collected Patient Writing, Volume One] (1937). 
and seek donations to further their activities in Shikoku's public Hansen's Disease hospital (Author, 2012). Whereas the short stories published by the Leprosy Prevention Association overstated the institution's ability to cure sufferers and the possibility of reintegration into society after successful treatment, the materials used by other medical or relief organizations and Christian missionaries described the hospital in more muted tones as a place of advanced treatment while underscoring the institution as a haven from the discrimination sufferers faced.

Owing to the at times blurred and complicated uses of patient literature, the writings published by the Leprosy Prevention Association were not included in the recently released 10-volume set entitled, Collected Works of Hansen's Disease Literature (Ōoka Makoto et al, 2002-2010) wherein the voices that wrote in support of government isolation policies are largely absent. Yet, this exclusion is a misguided attempt to qualify what constitutes patient writing, and is dismissive of voices that expressed support for government policies and happiness with institutional life. To disregard writers who supported government policy is to impose a post-Promin perspective on these texts and to ignore the conflicted and plural nature of leprosy literature. The current narrative does not take into adequate account that for some patients, institutionalization was preferable to social reality.

Writing by patients who supported government policies is dismissed because it appears to contradict the narrative of triumphant patient protest and government oppression that until recently remained dominant within post-Promin scholarship. Studies of Hansen's Disease, particularly by Fujino Yutaka and like-minded historians, tell the story of Japanese legislation against the disease as one of draconian medical fascism, where increasingly repressive and invasive prewar health policies are in the postwar period successfully fought by patients. ${ }^{17}$ Told this way, the history of Hansen's Disease in Japan is a post-Promin story of triumph over oppressive government policy. ${ }^{18}$ Writing demonstrating patient contentment or institutional happiness is consequently ideologically filtered and judged supportive of what Fujino describes as "fascist" health policies (Fujino 1993). Indeed, the studies of patient writing, and in particular the Collected Works of Hansen's Disease Literature by Kōseisha have been selective in the analysis and canonization of Hansen's Disease literature. Cary Nelson's writing on American leftist poetry can prove particularly pertinent to flagging such distortions: "considerable damage can be done by unqualified devotion to a single master narrative [...] To be in thrall to a single historical narrative [...] is to miss the benefits that come from juxtaposing multiple, competing narratives" (Nelson, 1989, p. 7).

\section{Different Translations of Happiness in Leprosy Literature}

Poetry in Japan has long been used to commemorate life events, and even death. The tradition of composing a final poem, known as "death poetry" (jisei), dates back to at least the seventh century, and countless collections of famous final poems have been published in Japanese. Furthermore, the modernization of tanka was led by Masaoka Shiki (1867-1902), who suffered from tuberculosis. Shiki promoted a style of poetry that reflected everyday life and experience, arguing that the form of tanka should be accessible to all, from writers to members of the general public. Uchida Mamoru (pen name Uchida Morito), a doctor at Kyushu Hospital and an active poet in his own right, promoted tanka composition among patients believing the style of writing especially suited to amateur

17 Fujino Yutaka $(2001,2010)$ has published a series of books on Hansen's Disease in Japan, which denounce the Japanese government's oppression of hospital residents.

18 For two examples of recent revisionist scholarship challenging the dominant historical narrative of Hansen's Disease in Japan, see Hirokawa (2010) and Arai (2011). 
poets and appropriate for writers in public hospitals struggling with debilitating illnesses, in particular Hansen's Disease or tuberculosis (Uchida, 1940). The suitability of this expressive and meditative style for patient writers came not only through the accessibility of form but also from the stylistic tradition of memorializing life and its struggles. Tanka captured the poetry of everyday life, recording not only daily experience in the hospital but also commemorating those whose actions impacted the writer, or memorializing not only one's own death but the death of companions.

Poems highlighting patient struggles with illness, infirmity, and death were often used in hospital leaflets. Yet at the same time, the poems also describe the comfort residents found in the care of doctors who dedicated themselves to treatment, as well as a gratitude for the institution itself. For example, a 1927 pamphlet advertising Kyushu Hospital includes a poem written by Kanemaru Yüichi, part of the Hinokage (Shade of the Cypress) patient coterie:

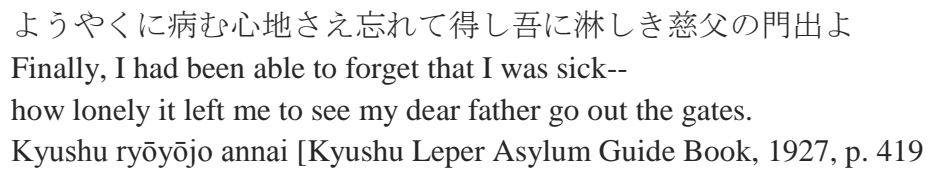

The poem, written when the hospital director, Kawamura Masayuki (1878-1933) left the institution to travel in Europe, reveals Kanemaru's gratitude. Rather than a repressive personage, for many patients the hospital director was a paternal figure, an object of reverence. ${ }^{20}$ Tanka such as Kanemaru's were therefore by no means rare, as patients repeatedly penned their appreciation for the care and attention they received from doctors, nurses, and the medical staff. Similarly, Hiranabe Kyōtō expressed respect towards Mistuda Kensuke (1876-1964), director of Tokyo's Zensei Hospital (today Tama Zenshō-en): ${ }^{21}$

回診の院長さんともの云ひて何かうれしく心なごめり

Exchanging words with the hospital director during his rounds, I became happy, my heart comforted (Miyakawa, ed., 79)

The use of poems that expressed gratitude or thanks to doctors in promotional materials has led later scholars to disqualify them despite the fact that the poems were first published in coterie magazines and are part of the literary traditions of the hospitals. As is clear in these examples, the gratitude and comfort expressed toward the

19 All translations in this essay are the author's own. I have attemped to capture the hermeneutic meaning of the poem rather than follow the syllable pattern of the Japanese original.

20 Kawamura was of such importance to the Hinokage coterie members that upon his passing they published a poetry collection dedicated to his memory (Kyushu ryōyōjo Hinokage kai, 1935).

${ }^{21}$ Mitsuda Kensuke is the most prominent and perhaps the most controversial figure in studies of the history of Hansen's Disease in Japan. After working in the Tokyo Hospital he became the first director of Nagashima Aisei-en. He was a strict segregationalist and fervent supporter of Japan's isolation policies, testifying to the necessity of continued quarantine in 1951 after the illness was curable. Historians have vilified him because of his support of quarantine and eugenic policies, but as Hiranabe's poem reveals, many patients felt grateful for his work on their behalf. 
medical staff and facilities within patient writing is an important source of happiness in the pre-Promin institution that is elided by the current historical narrative, which overlooks gratitude and institutional happiness as an authentic expression of a dimension of institutional life.

In addition to expressing gratitude to doctors, many writers also used poetry to express their appreciation of the imperial family's monetary donations and praised the tanka of Empress Teimei (1884-1951) composed on their behalf (Arai, 2011). ${ }^{22}$ For sections of the hospital coteries, gratitude to the nation educed their literary production as part of Japan's fight against Hansen's Disease. Indeed, the growing attention given to the fight against Hansen's Disease in the mass print media of the day paralleled the increased awareness of patient writing and its possible social purposes. The 1930 collection of poetry published by Musashino Kakai (Musashino Poetry Society), a group from Tokyo's Zensei Hospital (today called Tama Zenshō-en), opens with, "The Veil of Daybreak; now is the dawn of the leprosy movement" (p. 1). These words are prophetic, for as noted above, 1931 witnessed the revision and strengthening of the Leprosy Prevention Law, as well as the establishment of the Leprosy Prevention Association.

To encourage patients to seek treatment for their illnesses in public institutions, the Association not only held film viewings, sponsored lectures, and published pamphlets underscoring the contagious rather than genetic nature of the illness, but in the late 1930s the Association also published collections of patient prose that were written in support of isolation policies. In his discussion of the Leprosy Prevention Association, Arai astutely argues that this literature written by patients was the most persuasive argument for the institutionalization of sufferers following home treatment. Through patient writing that was published in support of government policies, Arai asserts that sufferers came to see the disease as a familial, social, and ultimately national shame which proved the greatest of all appeals.

Such writings were published in part because patients themselves promoted government policies of isolation for Hansen's Disease sufferers, revealing an active process of translation and belief in the duty of Hansen's Disease sufferers to the nation. In the short stories collected and published by the Leprosy Prevention Association, the physical space of the hospital is typically represented as a utopia and imperial blessing, especially when contrasted with the stigma of society. Brett Walker (2010) has argued that the experience of suffering or pain on behalf of the nation was a central ingredient in producing a sense of national community. To suffer for the nation was to be a citizen of that nation, and to be in pain for the greater good of the country was seen as a national duty: "[...]all modern nations, including the Japanese one, require pain and acceptance of that pain from their subjects and citizenry, particularly at key historical moments. The act of interpreting and contextualizing such pain as dignified national sacrifice is critical to state legitimacy [...]" (p. 9) While Walker is referring specifically to diseases caused by environmental toxins associated with industrial progress in Japan, his point that the nationalization of bodies is

22 The poem composed by the Dowager Empress Teimei in 1932 became the most frequently reprinted poem in material promoting government policies and soliciting donations:

つれづれの友となりても慰めよゆくこと難きわれにかはりて

Be their companions, help them while away those lonely hours

In my stead, who cannot easily visit

For more on Empress Teimei and patient reactions to her poetry as well as her charity work with sufferers, see Arai (2011). 
predicated in part on suffering on behalf of the nation-building project is directly applicable to the situation of residents in Japan's national Hansen's Disease hospitals.

Patient writing provides a lens through which to investigate the ways in which national policies were translated by the hospital, by the Leprosy Prevention Association, and ultimately by the patients themselves. The Association published four collections of short prose, three of which were solicited with the idea that the accounts of patient experiences would become the basis of educational films. The manuscripts were published under the name Collected Patient Compositions: Materials for Movies (Kanja sakuhin eiga sozaishū), volumes 1-3. A fourth collection of short stories was published under the name Collected Patient Compositions, Volume One (Kanja sakuhin shū dai isshū). ${ }^{23}$ The titles of the pieces chosen for publication are suggestively (if not strategically) optimistic with titles such as, "Spring in Paradise," "Shining Paradise," "The Light of Misfortune" from the first volume, "Our Blue Sky," "A Blessed Paradise," from the second, and "Autumn in Paradise," and "The Brightness of the Island" from the third volume of works. Such tales typically follow the same narrative pattern: a peaceful village life is disrupted by the shock diagnosis of Hansen's Disease; despair of illness sets in before the sufferer turns to the hospital to receive care, acceptance and treatment as a patient. The stories end either with the complete cure and discharge of the protagonist or their discovery of complete institutional contentment (Arai, 2011 and Author, 2012). In many cases, the authors depict cured patients continuing to work to rid Japan of Hansen's Disease, either by spreading word about the treatment and comfort of hospital life, or by continuing in the hospital as a staff member following their cure.

Nagata Honami (1891-1945) contributed a piece titled "Torikaesu hikari" [Recovering the Light] to the first Leprosy Prevention Association collection. In it he depicts the story of Keikichi and his lover Satoko, both of whom are diagnosed with Hansen's Disease. ${ }^{24}$ Keikichi undertook a difficult pilgrimage in search of a cure while Satoko was quarantined in a single room in the family home. They both decide to enter the hospital together, where they find "life in an ideal paradise." The story ends with Keikichi's cure and the doctor's entreaty that Keikichi returns to society and "exert [yourself] for leprosy prevention and the purification of the nation." Satoko's fate is unknown (Nagata, 1933).

Likewise, the lead story in the same collection by Fumoto Karei (1907-1943) entitled "That Morning" [Sono Asa] depicts two families whose sons are diagnosed with Hansen's Disease. In the case of the Ozaki family their heir is diagnosed with the illness and they are driven from their home. When they settle in a new area, the stigma follows and culminates in the suicide of the entire family. In the case of the Kimaki family, the father dies of Hansen's Disease and the eldest son Ken'ichi is also diagnosed. After several suicide attempts and efforts to treat the disease at home Ken'ichi goes to the hot springs of Kusatsu for treatment, where a village of Hansen's Disease sufferers was established. When his mother can no longer meet his exorbitant financial demands, Ken'ichi runs away with a prostitute to hide himself in Tokyo. Ken'ichi's younger brother Ryōji, who has also been diagnosed with the illness, discovers the pair. Ryōji informs Ken'ichi that the latter's prodigious expenditure at Kusatsu has ruined the family finances, and Ryōji has no choice but to enter a public hospital. He urges Ken'ichi to accompany him, as Ken'ichi's current lifestyle is spreading the illness. Ken'ichi scoffs at Ryōji, claiming the hospital is for the

${ }^{23}$ The "volume one" in the title indicated that more volumes were expected to be published but none were, perhaps indicating a waning patient interest in writing for the Association.

24 Nagata's name is more commonly read Osada Honami, but his work has been translated by Lois Erickson into English under the name Nagata. For more, see Author (2012). 
moralistic "goody two-shoes" types. Undaunted, Ryōji goes alone to the hospital and finds it a "peaceful place to live," where everyone helps each other out. He finds work in the patient publishing house, urging patients living outside the hospital be admitted for treatment. After two years, Ryōji is allowed out of the hospital on a home visit. Imagining the delight of his mother and youngest brother, Ryōji enters the home only to find Ken'ichi exposing his rotted face and limbs in an attempt to extort money from his mother and youngest brother. Ryōji furiously announces: "I am already completely cured. I am contagion free and can be discharged, but because I am still concerned I intend to be readmitted to the institution, and while I undergo thorough treatment I intend to work in the hospital." Ken'ichi, whose illness has progressively worsened, is so impressed that the two return to the hospital together. The story ends on the beautiful morning of the anniversary of the imperial donation to the hospital when the brothers enter the institution together (Fumoto, 1933, 1-5).

It is easy to read such examples as representative of coerced production of what the Leprosy Prevention Association felt would be most effective to support government isolation policies. As Arai (2011) has argued, the Leprosy Prevention Association materials were collected and published with the express purpose of encouraging the institutionalization of new patients. Rather than dismiss these works as promotional materials for government policies, however, a careful reading of the stories collected can reveal the process of translation between social discrimination and institutional life in the hospital. The stigma patients faced in their homes and villages that is described in these stories was not fabricated; it mirrored social reality. Indeed, it can be argued that it was because stigma was so severe that patients were willing to be imbricated in the process of translation with the Leprosy Prevention Association.

The treatment of patients outside the hospital is made clear in these works. In Satoko's case, she was forced to live hidden in a single room; Keikichi makes an arduous pilgrimage in vain. The diagnosis of their son drives the entire Ozaki family to suicide. The fate of the two brothers in Fumoto's piece is perhaps most telling; although Ken'ichi mocks the idea of treatment, his illness disfigures him, bankrupts the family and brings shame upon them. In convincing his brother to enter the hospital, Ryōji saved the family and Ken'chi not only from the stigma of Hansen's Disease but also from the morally corrupt lifestyle uninstiutionalized patients were perceived to maintain. Through entering the hospital, Ken'ichi reclaimed his status as a filial son and a dutiful Japanese citizen. Ryōji fulfilled his role as a model patient, first by working to publish materials urging patients to seek treatment, then by convincing his brother to seek treatment, and finally by readmitting himself for further treatment despite his official status of "completely cured."

The Leprosy Prevention Association pieces often depict the treatment and cure of the illness as a source of patient happiness within institutional walls, for in both works discussed here, a sufferer is "completely cured." In contrast to this, rather than finding joy in cure, poets most often expressed happiness in the idea of the hospital as a haven and refuge. Thus, writings published by the Association at once highlight support of government policies as a source of healing and happiness while at times downplaying the happiness writers found in the escape from the extreme stigma they faced; the powerful process of translation is reflected in this balance of government needs, underpinned by sincere sources of happiness.

But it was not just writers for the collections published by the Leprosy Prevention Association who found happiness in their hospital lives and the sense of duty as Japanese citizens. Writers in poetry coteries were also motivated to express their sources of happiness in the institution and the fulfillment of their obligations as a Japanese citizen. In this sense, the representations of patriotism and prejudice in the Leprosy Prevention Association collections were not an unusual occurrence. Consider, for example the following poems by Yoshimatsu, written in 1931: 
日の本ゆ癩を除かん心こそ現在の日本を愛す心ぞ

Drive leprosy from the land of the rising sun-

That is the heart of love for the land today

In a second poem from the same collection, Yoshimatsu expressed:

活動のビラと並べて療養所のありどの知らせ張らばともがな

Along with our action flyers, there is one about the hospital.

Which notice shall I post?

(Miyakawa, 1930, p. 89)

Yoshimatsu's poems reveal not only a sense of belonging to a national community as driving the fight against Hansen's Disease, his compositions also reveal patient participation in the production, circulation and dissemination of promotional literature. As Hirokawa (2010) has argued, the policies of the Japanese government that mandated quarantine, along with the social movements of the Leprosy Prevention Association and the Leprosy-Free Prefecture Movement, contributed to a growing awareness of the illness as contagious and fearsome, increasing the social stigma patients encountered. In part because they believed fellow sufferers would be happier inside the hospital than out, hospital residents played an active role in the circulation of material about the hospitals and the Hansen's Disease relief movements in Japan. In the first poem, Yoshimatsu clearly expresses that his love for Japan is rooted in the socio-politico movements seeking to eradicate the illness; in the second poem, "action flyers," presumably from relief organizations, signal his devotion to the cause. Yoshimatsu's poems reveal not only acceptance of personal sacrifice as dutiful servitude, but an embrace of government policies to rid Japan of Hansen's Disease. Poems such as Yoshimatsu's demonstrate that not only was patient writing used to encourage institutionalization, but that literature praising and actively participating in relief efforts was produced even when not solicited by the Leprosy Prevention Association.

Sufferers that writers such as Yoshimatsu sought to reach were those being treated at home, as was the case with Hayashi Yukiko, a poet eventually institutionalized at Nagashima Aisei-en. In a series of poems entitled "With My Blind Husband," written for the Nagashima women's poetry circle Hagi no kai (Bush Clover Society), Hayashi describes her journey with Hansen's Disease and the social conditions which made the hospital a haven. Upon her diagnosis of Hansen's Disease, Hayashi withdrew from her position at the post office, and was subsequently quarantined in a small, dark room in her family's home for more than a year before being admitted to Nagashima Aisei-en. Although the tale of a Hansen's Disease patient kept in a dark back room or a shed was commonly sensationalized in the plot of many stories, both by sufferers, doctors, as well as fiction or detective novelists, it was also a reality for a number of patients. ${ }^{25}$ Such experiences were also related in essays or short stories; in one particular autobiographical account solicited as a part of a collection of patient testimonies by the Home Ministry, a young woman of sixteen recounted: "I couldn't possibly go outside; I was unwillingly quarantined in a single room." Thus she was "deeply grateful for the imperial blessing" of the hospital (Rai yobō kyōkai and the Home Ministry, 1934, 435-436). As with the young woman, Hayashi's journey with her illness also culminated in gratitude for the hospital. Indeed, the contrast between life within and outside the institution were for her stark, for while she was under home treatment, Hayashi wrote of the loneliness, the darkness, the mice, and of how she would press her

${ }^{25}$ For more on sensational literature and detective stories featuring Hansen's Disease, see Burns (2004). 
ear to the cold wall to try and hear family life beyond the room:

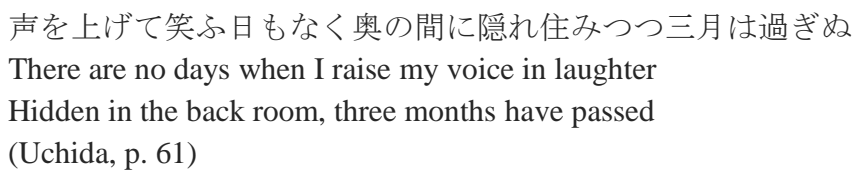

Silent and hidden in the backroom while her family continued to discuss her fate, Hayashi relates how her illness worsens; when she begins to show unmistakable physical symptoms such as the loss of her eyebrows, her family thus reacts:

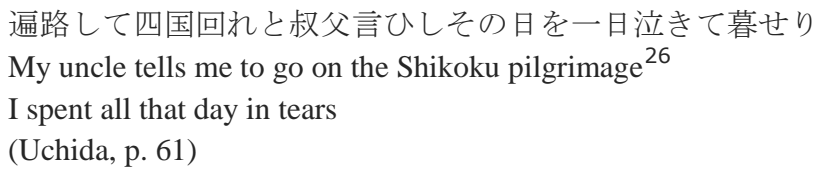

Conscious of her family's possible alienation from the wider community, Hayashi's tears suggest an overbearing fear of pilgrimage rather than an underlining hope for a cure. In his autobiography, Nagata Honami too noted that the Shikoku pilgrimage was a way to protect his family from ostracization: soon after his diagnosis, Nagata overhears his father and aunt discussing his condition and his aunt's recommendations for the concealment of his illness: "Send him on the Shikoku pilgrimage. If he's out of sight we'll feel safer, and wouldn't he be more cheerful on his travels [...] There's also the fact that, right now, [his illness] is just a rumor and to look at him you wouldn't really think he had leprosy, so it's a good time for him to go [...]" (Nagata 1931, 16; quoted in Author 2012, 116).

For writers such as Nagata and Hayashi, so great was the fear of being discovered that they voluntarily sought hospital admittance. In Nagata's case in particular, his family was able to financially provide home care, and thus under the 1907 law he did not qualify for admittance into a public institution. Nagata's autobiography recounts the way in which he pressed his request so fervently that finally he was allowed to enter the institution (Author 2012). That the hospital provided relief from the travails of the Shikoku pilgrimage or the life of an itinerant beggar, or even that it could protect the family from ostracization, meant that rather than being a last resort, in many cases admission into the hospital was the most viable solution, and a desirable refuge for sufferers.

Hayashi did not undertake the pilgrimage, and her poems underscore the continued misery of home isolation. Intense unhappiness under quarantine is the consequence:

26 The Shikoku pilgrimage was a tour of eighty-eight temples on the Japanese island of Shikoku and it was commonly believed that if a sufferer of Hansen's Disease completed the arduous journey of several hundred miles to visit each temple they would be cured of their illness. Patients traveled to Shikoku from all over Japan, and the tour was by no means a safe one; patients were robbed, beaten, and faced discrimination along their travels. Women who traveled the pilgrimage faced the danger of being raped. Despite this, for many families, the pilgrimage was a way to be rid of a sufferer under the guise of spiritual cure. 
奥の間の闇きが中に隠れつついつしか鼠の友を得にけり

Hiding in the darkness of the backroom

I gained the friendship of the mice

(Uchida, p. 62)

鼠等の静かなる日は由貴子われ何かさびしく小空見て居り

On days when even the mice are quiet

Lonesome, I look out the small window

(Uchida, 62)

Conveying the bleakness and desperation of solitude, Hayashi's poems are punctuated by descriptions of tears, silence, and predominantly, by the fear she will be discovered:

夜おそく逃ぐる如く家を出て人目避けつつ駅にゆきたり

Leaving home late at night as if in flight

I make my way to the station, avoiding the eyes of the villagers

(Uchida, 62)

Yet for Yukiko, happiness defined as relief begins with the mere thought of the hospital, which signals a dramatic shift of sentiment and the language she uses in her poems reflect a different, more hopeful psychological reality:

療養にゆく日待ちつつ我が心新しき望みにも思ひ居り

Waiting for the day I go to the hospital

I seem to hold new hopes in my heart

(Uchida, p. 62)

In fact, the hope she describes in the poem above is realized, as institutionalization brings with it psychological and physical freedom, both lived and imagined:

今日よりは誰れ憚からむ天地に足駄鳴らして歩まんぞわれ

Beginning today, whom should I fear?

Let my footsteps resound as I walk the world

(Uchida, p. 63)

For Hayashi, despite its restrictions, the hospital is a place of collective support and a poetically declared equality where there is the possibility "to be" without fear. The moments of happiness and brightness Hayashi describes contradict scholarship, in particular studies that focus on the cruelty of marriage in the hospital, characterized as it was in the Pre-Promin era by forced eugenic surgery to prevent pregnancy and a refusal to allow spouses to live together. Hayashi's poems depict the time the couple spends together as cheerful, and the comfort they provide each other as their illness worsens: 
白白と続く細道夫が杖とりて歩みつ蝉の声聞く

The bright, narrow path stretches on

My husband ${ }^{27}$ walks with his cane, listening to the cicadas

(Uchida, 71)

Despite the suffering caused by her illness and familial separation, Yukiko's poems convey the sense of happiness and brightness within the walls and collectivity of the institution. Yet while voices like Yoshimatsu's and Hayashi's encourage institutionalization, they also reveal a more subtle process of negotiation with the different forces that drive patients to seek shelter and (re)discover happiness. And while Yoshimatsu's poems describe both an acceptance and a promotion of government policies, Hayashi's reflections reveal more subtle translations of social stigma and government policy, where institutionalization becomes both a strategy and means of happiness.

\section{Conclusion}

Literature reflects a complicated process of translation; there are multiple voices and experiences conveyed through the writing of institutionalized sufferers. There were, of course, those patients who used literature to express their dissatisfaction with hospital life and their relative lack of autonomy within such institutions. For those who did not embrace the calls for national sacrifice or the notion of the hospital as a haven from stigma, the process of finding happiness in the hospital was a more complex process of translation. As the poet Ōtake Shimao wrote in 1930:

全生病院のよきところのみ語りみぬ心寂けく茶を飲みにけり

Only able to relate what a good place Zensei Hospital is

I drank my tea with a lonely heart

(Mitsuda, 1937, p. 64)

To take another example, Aratani Nanpa (years unknown) was a frequent contributor to the Hinokage coterie and its publications at Kyushu Hospital. In its first collected volume of patient poems, an editorial note explains the context of some of Aratani's contributions: "He snuck out of the hospital to see his children who were being cared for at a nursery in Osaka, but he came back without realizing his objective; following to the institution's prescribed punishment he was put in jail" (Kawamura \& Uchida, 1926, p. 18). Aratani writes of his experience:

がさがさと落葉をさそう風の音監房の夜はいよいよ淋しき

The sound of the wind invites the rustling leaves to fall

Nighttime in the cell is lonelier than ever. (Kawamura \& Uchida, p. 18)

Aratani's poem not only reveals patient discontent with policies that separated sick families from their healthy children, but it also exposes the punishment system in place at the hospital. The existence of the hospital jail

27 Patients were separated into male and female dormitories, and married couples were allowed visits around the grounds or occasionally in the wife's room. For more on marriage in the hospital, see Author (2012) and Yamamoto and Katō (2008). 
was never mentioned in promotional material; in the majority of pamphlets, the separation from the family that institutionalization entailed was not addressed. Hospital and Leprosy Relief Association pamphlets instead stressed the fact that patients could receive visits from families at the institution, and the fact that if the patient was in a non-infectious state, the hospital authorities would also grant permission for short home visits. Aratani's poem thus reveals his effort to maintain a sense of autonomy within the quarantine facility, and his desire to maintain his family ties on his own terms. While his visit to his children was unsuccessful and resulted in punishment, the poems reveal that the process of translating the hospital's goals was not always successful, and patients did rebel.

It is also significant that Aratani returned to Kyushu Hospital and continued to be active in the literary coterie. While patients did sometimes run away or leave the hospital without permission, many returned because the stigma they faced outside the hospital did not abate or their worsening condition forced them to again seek treatment as they could no longer support themselves. In this sense, happiness in the hospital was the result of a process of translation wherein life within the hospital was more tolerable than the discrimination and prejudice that patients faced from society, and sometimes even from their families. In these ways, patient happiness was a process of translation that was worked out, in part, through patient writing. Attention to the broad spectrum of patient writing reveals the multiple ways in which patients defined happiness within the institution. In this sense, leprosy literature was a site of translation involving hospital authorities, patients, leprosy relief groups, social stigma, and government policies. Residents of the hospital represented happiness in multiple ways depending on their conception of their illness and life in the hospital. For some patients, an escape from social stigma and the sense of duty to the nation was a source of happiness. For others, they chafed at the forcible quarantine and life in the hospital. In their poems, the process of translation is a more complex process. In the end, most patients were able to find moments of happiness, even if that meant escaping from the eyes of the medical authorities for just a moment, as Ota Kaō writes in a haiku from 1926:

\section{医に秘して買はする酒や花曾}

A cloud of cherry blossoms with sake purchased in secret from the doctors

(Kawamura \& Uchida, 1926, p. 42)

Happiness for a great many of the patient population in the pre-Promin hospital came from a variety of sources: it came from the fact the hospital provided a haven from social stigma, and from the kindness sufferers found in missionaries or medical staff, and it came from a sense that their sacrifice served the greater good of the nation. To be sure, the hospital was a difficult place where residents surrendered basic human rights such as freedom and reproductive rights, and were forced to endure hardships such as separation from their families and their hometowns, but for some, these sacrifices were worth the freedom from stigma, the peace and the rediscovery of peace that they found in the hospital. A walk with a spouse or a small cup of alcohol under a cloud of cherry blossoms, not possible for them outside the walls of the hospital, was possible within them. To try and read all patient writing so as to locate a condemnation of human rights violations, or to underscore the misery of the pre-Promin hospital is to miss the happiness and contentment that some patients did find and indeed, recover and rediscover in the hospital. 


\section{References}

Abel, J. (2012) Redacted: The Archives of Censorship in Transwar Japan. Berkeley and Los Angeles: University of California Press.

Akashi, Kaijin. (1939) Hakubyō [Ink sketches]. Tokyo: Kaizōsha.

Akashi, Kaijin. (1941) Akashi Kaijin Zenshū [Complete Works of Akashi Kaijin] 2 vols. Tokyo: Kaizōsha.

Akashi, Kaijin. (1993) Kaijin Zenshū [Complete Works of Kaijin]. Edited by Muramatsu Takeshi, et al. 3 vols. Tokyo: Kōseisha.

Anderson, W. (2006) Colonial Pathologies: American Tropical Medicine, Race, and Hygiene in the Philippines, Durham: Duke University Press.

Araragi. Y. (2004) "Yamai no keiken" wo kikitoru—Hansen-byō-sha no raifu historī [Listening to the "experience of illness"-The life histories of Hansen's Disease Sufferers] Tokyo: Kōseisha.

Arai Y. (2011) Kakuri no bungaku: Hansen-byō ryōyōsho no jiko hyōgen-shi [Literature of Quarantine: A History of Self-Expression in Hansen's Disease Sanatoria]. Tokyo: Shoshi arusu.

Aranami C, (2000) Yomigaeru "Manyō kajin" Akashi Kaijin [Akashi Kaijin: Reviving the "Man'yō Poets"]. Tokyo: Shinchō-sha.

Baba J. (2004) "Ikan, Uchida Mamoru to geijutsu undo" [Doctor Uchida Mamoru and the Art Movement]. In Rekishi Hyōron [History Review] No. 656, 20-32.

Burns, Susan L. (2003)“From 'leper villages' to leprosaria: Public health, nationalism and the culture of exclusion in Japan.’In Bashford \& Alison (Eds.), Isolation: places and practices of exclusion (pp. 104-118). New York: Routledge.

Burns, Susan L. (2004) "Making Illness into Identity: Writing "Leprosy Literature" in Modern Japan." In Japan Review 16, 191-211.

Burns, Susan L. (2012) "Rethinking "Leprosy Prevention:” Entrepreneurial Doctors, Popular Journalism, and the Civic Origins of Biopolitics,” Journal of Japanese Studies 38 (2): 301-327.

Coulmas, F. (2009) Die Illusion vom Glück: Japan und der Westen. Zurich: Verlag Neue Zürcher Zeitung.

Edmund, R. (2006) Leprosy and Empire: A Medical and Cultural History, Cambridge: Cambridge University Press.

Fujino, Yutaka. (1993) Nihon fashizumu to iryō-Hansen-byō wo meguru jisshō-teki kenkyū [Japanese Fascism and Medicine: Evidence-Based Research on Hansen's Disease]. Tokyo: Iwanami shoten.

Fujino, Yutaka. (2001) 'Inochi' no kindai shi: 'minzoku jōka' no na no moto ni hakugai sareta Hansen-byō kanja [The Modern History of "Life:"Hansen's Disease patients who were persecuted under the name of "racial purification"]. Tokyo: Kamogawa shuppan.

Fujino, Yutaka. (2010) Sensō to Hansen-byō [War and Hansen's Disease]. Yoshikawa Kōbun-kan.

Fumoto, K. (1933) That Morning [Sono Asa]. In Rai yobō kyōkai [Leprosy Prevention Association] (Ed.), Kanja sakuhin eiga sozaishū dai isshū (Vols. 1) [Collected patient compositions-Materials for movies] (Vol. 1, 1-5), Zaidan hojin rai yobō kyōkai.

Gussow, Z. (1989) Leprosy, Racism, and Public Health: Social Policy in Chronic Disease Control. Boulder: Westview Press, Inc. 
Hirokawa, W. (2010) Kindai Nihon no Hansen-byō mondai to chiiki shakai [Modern Japan's problem of Hansen's Disease and local communities]. Osaka: Osaka University Press.

Hōjō, Tamio. (1938) Hōjō Tamio Zenshū [Complete Works of Hōjō Tamio]. Edited by Kawabata Yasunari. 2 vols. Tokyo: Sōgen-sha

Hōjō, Tamio. (1996) Teihon Hōjō Tamio Zenshū [Standard Complete Works of Hōjō Tamio]. Edited by Kawabata Yasunari and Kawabata Kaoru. $2^{\text {nd }}$ ed. 2 vols. Tokyo: Sōgen-sha.

Kawamura, M. \& Uchida M., (Eds.). (1926) Hinokage 1 [The shade of the cypress 1]. Kumamoto: Shiroishi insatsujō.

Kōno, K. (2009). Ken'etsu to bungaku--1920 nendai no kōbō [Censorhip and Literature--the Battle of the 1920s]. Tokyo: Kawade shobō.

Kosaka, K. (2003) A sociology for happiness: Beyond western versus non-western perspectives. Sociological Bulletin 56 (3), 369-382.

Kumano, M. (2011) Orientations to happiness in Japanese people: Pleasure, meaning, and engagement. Journal of Japanese Psychology 81 (6), 619-624.

Kurihara T. (1987) Ikiru hi no kagiri-Akashi Kaijin no hito to shōgai [The Limits of the Days of Existence-Akashi Kaijin, the person and his life] Tokyo: Koseisha.

Kyushu ryōyōjo annai. (1927) [Kyushu Leper Asylum Guide Book].

Kyushu ryōyōjo hinokage kai. (1935) Hinokage no seifu [The Divine Father of the Shade of the Cypress]. Kyushu: Kyushu ryōyōjo iankai.

Mitsuda K. (Ed.). (1937) Fūinshū [Shade of the maple collection]. Tokyo: Nagasaki shoten.

Mitsuoka R. (1981) Hōjō Tamio-Inochi no hokage [Hōjō Tamio: the light of life]. Tokyo: Okizumi-sha.

Miyakawa, R. (Ed) (1930) Shinonome no mabuta [The veil of dawn]. Tokyo: Nagasaki shoten.

Morita S. (2003) Shi to Hansen-byō [Poetry and Hansen's Disease]. Tokyo: Doyo bijutsu sha shuppan hanbai.

Nagata, Honami (Osada Honami). (1931) Chiisaki mono [One Small Person]. Kōchi: Reikō-sha.

Nagata, Honami (Osada Honami). (1933) Torikaesu hikari [Recovering the Light] In Rai yobō kyōkai [Leprosy Prevention Association], (Ed.), Kanja sakushin eiga sozai shū dai ichi gō [Patient Writing: Collected Materials for Movies Volume One], 159-165. Tokyo: Zaidan hojin rai yobō kyōkai.

Nelson, C. (1989) Repression and Recovery: Modern American Poetry and the Politics of Cultural Memory, 1910-1945. Madison: University of Wisconsin Press.

Ogawa M. (1938, reprint 2009) Kojima no Haru-Hansen-byō chiryō ni, shōgai wo sasageta aru joi no shuki [Spring on the Small Island: The Notes of the Woman Doctor Who Gave Her Life to the Treatment Hansen's Disease]. Nagasaki: Nagasaki shuppan.

Ōoka M., Ōtani, F., Kaga, Y., \& Tsurumi, T. (Eds.). (2002-2010) Hansen-byō bungaku zenshū [Collected works of Hansen's Disease literature], (Vols. 1-10). Tokyo: Kōseisha.

Oshio, T., Nozaki, K., \& Kobayashi, M. (2011) Relative Income and Happiness in Asia: Evidence from Nationwide Surveys in China, Japan, and Korea. Social Indicators Research 104 (3), 351-367. 
Rai yobō kyōkai (Leprosy Prevention Association). (1933) Kanja sakuhin eiga sozai shū dai isshū [Patient writing, collected materials for movies (Vol. 1) Zaidan hojin rai yobō kyōkai.

Rai yobō kyōkai (Leprosy Prevention Association). (1935) Kanja sakuhin eiga sozai shū dai ni shū [Patient writing, collected materials for movies] (Vol. 2) Zaidan hojin rai yobō kyōkai.

Rai yobō kyōkai (Leprosy Prevention Association). (1936) Kanja sakuhin eiga sozai shū dai san shū [Patient writing, collected materials for movies] (Vol. 3) Zaidan hojin rai yobō kyōkai.

Rai yobō kyōkai (Leprosy Prevention Association). (1937) Kanja sakuhin shū dai isshū [Collected Patient Writing, Volume One]. Zaidan hojin rai yobō kyōkai.

Rai yobō kyōkai (Leprosy Prevention Association) and the Home Ministry. (1934) Rai kanja no kokuhaku [Confessions of Leprosy Patients]. Zaidan hojin rai yobō kyōkai.

Rose, Nikolas. (1999) Powers of Freedom: Reframing Political Thought. Cambridge: Cambridge University Press.

Rose N. \& Miller P. (1992)"Political power beyond the state: problematics of government."The British Journal of Sociology, 173-205.

Sakata, K. (2012) Hansen-byōsha no seikatsushi-kakuri keiken wo ikiru to iu koto [A life history of Hansen's disease patients—Living with the experience of quarantine]. Tokyo: Seikyūsha.

Sawano, M. (1994) Raisha no sei—bunmei kaika no jōken to shite [The Life of Lepers; A Condition of Civilizaion and Englightenment]. Tokyo: Seikyūsha.

Shimada, Shakusō. (1934) Ichiaku no wara-Kashū [A handful of straw-A poetry collection]. Nagoya: Mizugamesha.

Shimada, Shakusō. (1939) Shimada Shakusō Zenshū [Complete Works of Shimada Shakusō]. Edited by Uchida Morito. Tokyo: Nagasaki shoten.Sumi, S. (1938) Sumi Seichō kashū [Sumi Seichō poetry collection]. Nihon MTL.

Takayama Fumihiko. (1999) Hibana: Hōjō Tamio no shōgai [The Spark: Hōjō Tamio’s Life]. Tokyo: Kadokawa bunko

Tanaka, K. M. (2012) Through the hospital gates: Hansen's Disease and modern Japanese literature (Doctoral dissertation). Available from ProQuest Dissertations and Theses Database. (Accession Order No. 3526363).Tō, K. (2006). Tō Kazuko Zenshishū [Complete Poems of Tō Kazuko].3 vols. Osaka: Henshū kōbō noa.

Tsuda, Haruko (1981). Tsuda Haruko zenkashū [Complete Tanka of Tsuda Haruko]. Tokyo: Ishikawa shobō.

Uchida, Mamoru (Uchida Morito). (Ed.(1939) Hagi no satoshima [Island home of Bush Clover]. Tokyo: Fujinkaisha.(1940) Ryōyō tanka tokuhon [Sanatoria Tanka Reader] Tokyo: Hakujūjikai.

Walker, B. (2010) Toxic archipelego: a history of industrial disease in Japan. Seattle: University of Washington Press.

Yamamoto, S. (1997) Zōho Nihon rai-shi [Expanded Edition: The History of Leprosy in Japan]. Tokyo: Tokyo University Press, First published 1993.

Yamashita, T. (2003) Umi no sasori: Akashi Kaijin to Shima Hiroshi: Hansen-byō bungaku no keifu [Scorpions of the sea: Akashi Kaijin and Shima Hiroshi: A genealogy of Hansen's Disease literature]. Tokyo: Michitani.

Yamada, T. (2009) Hansen-byō ryōyōjo ni okeru kikanshi no yakuwari to imi [The role and meaning of hospital journals in Hansen's Disease sanatoria]. Matsuyama Daigaku ronshū 21 (2), 137-157. 
Yamamoto S. and Katō N. (2008) Hansen-byō ryōyōjo no esunogurafī- "kakuri" no naka no kekkon to kodomo [An Ethnography of Hansen's Disease Hospitals-Marriage and Children Under "Quarantine"]. Tokyo: Iryō bunka-sha. 